\title{
PLANTS
}

\section{AN ODDITY: LICHENS GROWING ON AN OLD \& WEATHERED BABY SHOE}

BERNARD DE VRIES, 29 Hogan Place, Emerald Park, SK S4L 1C1

\section{Introduction}

Lichen studies and collecting often provide unexpected findings, such as rare species, new range extensions, unusual habitats or substrates. One such a surprise was a weathered baby shoe found by my wife, Irma, on June 25,2005 on an small patch of dry open grassland. This very weathered shoe about $14.5 \mathrm{~cm}$ long, appeared to be made of leather and canvas stitched with a white cordlike material to a lightcolored rubber sole, and had eyelets of hard white rubber (Figure 1). When found it was lying on the ground among scanty vegetation about halfway up an unstable slope showing signs of slumping. The site was $3 \mathrm{~km}$ south of Estevan across Woodland Regional Park's golf course in the Souris River Valley and on the west side of Highway 47 going to Port of Estevan at the U.S. border. The area is located in the Moist Mixed Grassland Ecoregion as part of the Prairie Ecozone ${ }^{3}$

The shoe was close to a clump of Prickly Pear (Opuntia polyacantha). Associated species were Hoary Sagebrush (Artemisia cana), Purple Cactus (Escobaria vivipara), and Creeping Juniper (Juniperus horizontalis), with grasses and terrestrial lichens such as: Fulgensia bracteata (Tundra sulphur lichen), Cladonia pocillum (Rosetted pixie-cup) and Xanthoparmelia chlorochroa (Tumbleweed shield lichen). Xanthoria elegans (Elegant sunburst lichen) and Xanthoparmelia mexicana (Salted rock-shield) were noticeable rock lichens nearby.

Several species of lichens and one species of moss could be identified on the shoe, mainly on margins of the upper surface and, to some extent, on the sides as well.

The following is an annotated list of these plants, which were identified by the author with scientific names, authors and vernacular names from several sources. ${ }^{1,2,4}$

\section{Annotated Lichen List}

Caloplaca cerina (Ehrh. ex Hedw.) Th.Fr. (Gray-rimmed firedot lichen), a common crustose lichen on bark especially in open woodlands, was found as scattered apothethia over the shoe's body, mostly on the upper weathered leather and canvas.

Caloplaca holocarpa (Hoffm. ex Ach.) M. Wade (Firedot lichen), a common crustose lichen on bark of various deciduous trees, growing as small colonies or as individuals on the upper body of the shoe and, to some extent, on the sides and upper inside surface.

Candelariella aurella (Hoffm.) Zahlbr. (Hidden goldspeck lichen), a common crustose lichen on exposed calcareous rock, occurred in small colonies often 


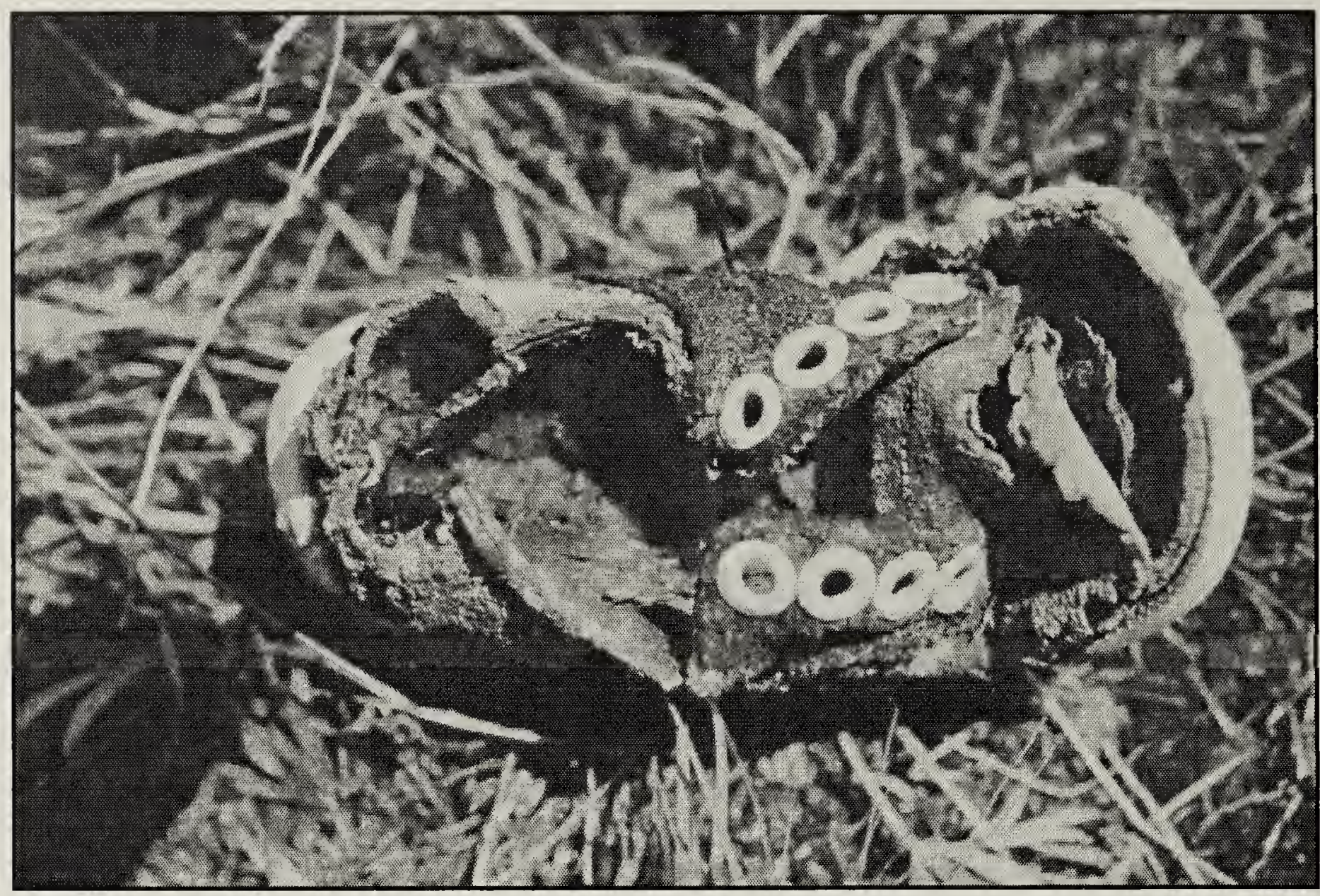

Figure 1. Weathered baby shoe found on 25 June, 2005

Bernard de Vries

with Firedot lichens on the upper side of the weathered leather and canvas of the shoe.

Lecanora hagenii (Ach.) Ach. (Hagen's rim-lichen), a small crustose lichen on bark or wood, was found thinly scattered on the upper leather margins.

Placidium lacinulatum (Ach.) Breuss (Brown stipplescale), quite common on dry soil, was found with Hidden goldspeck lichen on the lower side of the shoe on weathered canvas.

Xanthoria elegans (Link.) Th..Fr (Elegant sunburst lichen), a foliose lichen common on all sorts of rock, was only found as very small individuals on a few hard rubber eyelets.

\section{Annotated Moss List}

Tortula ruralis (Hedw.) Gaertn., Meyer \& Scherb. (Sidewalk moss), a common moss on calcareous soil or rocks and in rock crevices, was growing in a seam between the sole and the body of the shoe.

\section{Discussion}

The natural substrates upon which lichens grow-tree bark, wood, soil, mosses, lichens (parasitic), as well as on decaying wood or vegetation-are well known. However, lichens can also grow on various artificial substrates such as old glass, cloth, metal, plastic or leather, providing that the substrates resemble natural substrates in texture, chemistry and water-retaining capacities. For instance, lichens found on old glass are often associated with hard, siliceous rock, while those found on cloth are normally found on soil or dead vegetation. Lichens found on leather usually inhabit wood, and those found on plastic, metal or other material, are generally rock lichens not choosy about their substrates. ${ }^{1}$

This phenomenon was noticed to some extent in the lichens inhabiting 
the weathered leather, canvas and rubber of the shoe. For instance, Hagen's rim-lichen normally found on bark and wood was found on weathered leather; Elegant sunburst lichen occurring on all sorts of rock, found its niche on the hard plastic eyelets; Brown stipplescale, a soil lichen, was found growing on the weathered canvas of the shoe. These substrates provided a sustainable albeit artificial habitat for these lichens.

The ability of lichens to grow on manmade material or on old bone has often been observed by the author in the field. For instance, Xanthoria species (Sunburst lichens) have been found on old bone or deer skulls, and old, dirty car bodies or rusty farm implements may support a variety of lichen growth.

How this weathered baby shoe came to this site and its age will remain a mystery. It is not possible to know how long the shoe has lain on the ground. As the shoe was very weathered, it can be assumed that it was lost quite some time ago. The shoe itself could be 50 years old: it resembles a type of shoe introduced in the early 20th century sold under the brand name of "BAB-EES" Cushion Sole (Saddle Oxfords) and listed by Eatons in their 1955-1956 Fall and Winter catalogue.

How these lichens became established on the shoe at this particular site is another question. The shoe, like natural materials, offers a suitable substrate for certain lichen species to become established. Colonization via recent arrival of aerial born spores involves a complicated process whereby a fungal spore must recognize an appropriate alga to initiate a new lichen body. Wind-blown fragments from colonies of the same species found on soil or rocks in the same area, would be the more common avenue for these lichens to become established. Lichens are for the most part notoriously slow growers, and the fact that only small colonies or individuals were found on old weathered substratum, could suggest that although the shoe was quite old, the lichens growing on it were of recent origin.

\section{Acknowledgements}

I would like to thank my wife for discovering the baby shoe and for her assistance in field work.

1. BRODO, I.M., S.D. SHARNOFF, and S. SHARNOFF. 2001. Lichens of North America. Yale University Press, New Haven.

2. ESSLINGER, T.L. 1997. A cumulative checklist for the lichen-forming lichenicolous and allied fungi of the continental United States and Canada. North Dakota State University, Fargo, North Dakota http//www.ndsu.nodak.edu/instruct/esslinge/ chckl/chckl7.htm.

3. PADBURY, G.A. and D.F. ACTON. 1994. Ecoregions of Saskatchewan (Map). Agriculture and Agri-Food Canada. Available from Information Services Corporation, Saskatchewan.

4. JOHNSON, D, L. KERSHAW, A. MACKINNON and J. POJAR. 1995. Plants of the Western Boreal Forest and Aspen Parkland. Lone Pine Publishing, Edmonton.

"... swan song comes from the belief that the mute swan, silent all its life, sings a song just as it is about to die." 